\title{
Relevance and Strategic Review of Indonesia's Education Decentralization
}

\author{
Rishi Suparianto ${ }^{1}$, Faisal Santiago ${ }^{2}$ \\ Universitas Borobudur ${ }^{1,2}$ \\ \{Rishisuparianto@gmail.com¹, faisalsantiago@borobudur.ac.id²
}

\begin{abstract}
Decentralization of Education in Indonesia is a policy issued by the government in Education Law number 20 of 2003. Based on data from the Central Statistics Agency, several regions are still lagging in their education implementation. This research discusses the strategic issues that exist in the education decentralization policy in Indonesia, then will formulate alternative strategies for implementing decentralization in Indonesia. Through a qualitative approach with text analysis methods and primary data sourced from the Central Statistics Agency, it was found that there were three main issues in the implementation of decentralization of education. All three are issues of financing, quality control, and teacher professionalism. Based on these three issues, an alternative strategy is formulated, namely the cooperation between the central, regional, and educational institutions, so that the education decentralization policy can lead to improving the quality of education in Indonesia.
\end{abstract}

Keywords: Strategy; Policy; Decentralization of Education

\section{Preliminary}

According to data from the Indonesian Central Statistics Agency in 2018 the School Participation Rate (APS) for children aged 7-15 years in Indonesia reached 97.96\% with almost all provinces in Indonesia having an APS rate above 90\%, and only Papua has a figure at below $90 \%$ (Central Bureau of Statistics, 2018). The increase in APS is a form of progress in the development of education in Indonesia. There are still many other advances that have been achieved according to BPS data in 2018. The literacy rate in 2018 reached $95.66 \%$. Although still below the target of the Medium-Term Development Plan (RPJM), this figure indicates an increase or progress from 2017. However, it was found that the regions with the lowest literacy ratio were in Papua. The grade rate for students in grade 6 SD is $95 \%$, for grade 8 SMP is $96 \%$, for grade 11 SMA is $92 \%$. This figure shows one of the outcomes of the learning process. In addition to graduating rates, the survival rate up to grade $5 \mathrm{SD}$ is also quite high. In 2018 as many as $90 \%$ of students can stay in school up to grade 5 $\mathrm{SD} /$ equivalent. This indicates that there will be a student transition to a higher level of education. So that it can be seen that the achievement rate of continuing school for the SMP level is $93.47 \%$ and SMA is $85.50 \%$. Based on this data, it can be seen that there is progress in the learning process. Because the learning process is represented through the increase in 
student grades and the continuity of student education. The dropout rate for SD is $0.51 \%$, SMP is $1.67 \%$ and SMA is $2.94 \%$. The dropout rate indicates the government's success in encouraging its citizens to carry out the 12-year basic education program. Through this figure, it can be seen that the SD level has met the RPJM target, meaning that there has been a reduction in the dropout rate which indicates progress in education participation. However, the junior and senior high school levels have not yet reached the target. The passing rate for students aged 15-17 years in elementary education is $96.75 \%$, for ages $18-20$ years at the junior high school level is $85.54 \%$ and for ages, $21-24$ years at the high school level is $56.25 \%$. This means that the majority of the population from the age of 15 to 20 years at least completed education until elementary school and the rest completed up to junior high school. Even though at the SMA level there has been a decline or from the productive age population only a few finish up to the SMA level, at least they have completed their education up to the junior high school level.

At least there are several challenges faced by the government in improving the progress of education in Indonesia. The World Bank in its review notes that there are several challenges faced by the government in advancing education in Indonesia, namely: the high distance education between regions in Indonesia, an imbalance in income by community groups, and improving the quality of education. Looking at the data from the progress of educational attainment by the government until 2018, several challenges have been achieved by the government based on data from BPS (2018). The ratio of literacy rates in each province is evenly distributed, 9 out of 10 people in each province are literate. Meanwhile, the ratio of literacy rate in urban areas is 0.98 and in rural areas, it is 0.95 . With this ratio, there are very few obstacles to gaps or differences between rural and urban population groups. The distribution of each province is almost evenly distributed although there are still disparities in the Papua region. The survival rate in grade $5 \mathrm{SD} /$ equivalent for the population in urban areas is $94.57 \%$ while the population in rural areas is $94.32 \%$. For male students by $94.48 \%$ and female students by $94.43 \%$. Based on these statistical data, no imbalance or gap is too high for the survival of students both in urban and rural areas and for both male and female students. This proves that the government has succeeded in overcoming the problem of inequality and improving the quality of education in Indonesia so that there are not too many imbalances in student resilience in schools. The dropout rate for elementary school students in urban areas is $0.45 \%$ and in rural areas, it is $0.59 \%$, while for male students it is $0.59 \%$ and for female students, it is $0.44 \%$. The data also indicates that the government has made efforts to overcome dropouts of almost $0 \%$ in 2018 for elementary and equivalent levels. Inequality between rural and urban students as well as male and female students is also not very high because the average is only $0.10 \%$. The school graduation rate for $15-17$ years old who graduated for SD level/equivalent for urban areas is $97.93 \%$ and for rural areas is $95.37 \%$. The difference between these two regions is not too far away and proves the filling of the gaps that exist in rural and urban areas.

The explanation above proves some of the success of the government in overcoming at least three challenges faced in advancing education in Indonesia, namely broad regional problems, inequality at the social level, and also the quality of education [2]. However, there are still challenges that have not been resolved by the government. For example, the level of education of people with low and high socioeconomic levels is too high. For example, the level of tertiary education in the low socio-economic group is only $1.58 \%$ on average, while for people with high social economies the average participation is $23.98 \%$. Here it can be seen that there are still gaps and challenges that have not been achieved by the government. 
Looking at the explanation of the condition of Indonesian education, the decentralization policy of education in Indonesia has an important role in solving existing problems. The decentralization policy began with the end of the leadership era of President Soeharto and the entry of Indonesia into the reform era which is believed to be a description of democracy. This decentralization policy is a democratic act chosen by the government. The implementation of decentralization in the world of education itself is stated in education law number 20 of 2003. However, there are also obstacles in the implementation of this decentralization. This decentralization policy is also contained in Law Number 32 of 2004 which states that decentralization is the transfer of authority from the central government to regional governments. Based on Sutjipto's (2015) research, several government policies such as curriculum diversification can be implemented because of the decentralization of education and are evidence of the readiness of existing human resources. However, this policy still requires additions to meet the needs of the community.

Twenty-two years have passed since the reform in Indonesia however, the education decentralization policy still faces many challenges and obstacles. Based on the explanation above, it is found that there are still a lot of inconsistencies between the education decentralization policy and the practice in the field. Even though the implementation of this policy has been regulated in statutory regulations in 2003 . There have been at least 17 years since this policy was formally stipulated in statutory regulations. For this reason, this research will discuss what are the challenges in implementing the education decentralization policy in Indonesia, as well as alternative strategies that can be done to overcome these challenges.

\section{Research Method}

The approach to this research is qualitative. The research method used is a descriptive analysis of news documents and government reports that are open to the public. The data collected comes from education situation report documents which can be accessed openly by the public. Sources of supporting data are relevant online news. The data that has been obtained is then analyzed and the gap is seen with the existing statutory provisions. After the analysis is carried out, alternative strategies are projected to solve the problems found.

\section{Result and Discussion}

Based on research conducted by the World Bank, various problems exist in the world of Indonesian education. The various problems that exist according to the World Bank will be described as follows [2]:

a. There is no clear main function of the central and local governments in the implementation of decentralization of education in Indonesia. The regulations between the agencies dealing with decentralization are ambiguous and unclear. In essence, in the law, the roles of the regional and central government have been formulated, but in fact, the function of the regional government is still not clearly stated.

b. There is no clear parallel between the central and local governments.

c. Provincial governments do not have full authority over schools and government agencies under them. 
d. Not many local governments can implement the education decentralization program. Although there are only a few who can. The government in small areas is still unable to implement it.

e. The participation of the community, parents, and the private sector is still low.

f. There is no clear mechanism for organizational and personal accountability.

g. There is no adequate infrastructure in each region that can be connected. If you look at current developments, infrastructure is still in the development stage but cannot be used optimally because it is not yet connected.

Looking at the problems found above, there are at least three main problems behind the challenges of decentralization of education in Indonesia. For this reason, the three main problems will be discussed as follows.

\subsection{Budgeting Management in Decentralization of Education}

In terms of implementation and government regulations, the government does not necessarily escape from the obligation to provide financing in Indonesia. The government continues to develop laws and regulations to facilitate the financing needs of education in Indonesia [3]. Because after all, the evidence is that $20 \%$ of the state budget is aimed at developing the world of education [4]. This shows that the government does not just let go of its hand in matters of education financing under statutory regulations. Fironika in her research stated that the components of education financing are operational costs, investment costs, and personal costs. These three components constitute components that structure education financing [4] Moreover, this law also emphasizes again that at least $20 \%$ of the APBN and APBD are budgeted for the costs of the education sector. Furthermore, based on Imron (2016) it was found that based on Law of the Republic of Indonesia Number 2 of 1989 it was explained that the sources of education funding also came from the central government, local governments, students to international grants [5]. This financing source policy is the basis of financing policy in Indonesia. Furthermore, Government Regulation no. 19 of 2005 also regulates the national education standards in which this PP regulates the types of education financing which are divided into three. Before this regulation, according to Fironika (2015), the Minister of Education's Decree on Minimum Service Standards (SPM) for education was issued through Kepmendiknas No.53/U/2001. In this decree, it is stated that the MSS for education is a measure of the performance of education delivery services in provinces and districts/cities. This decree refers to PP No. 25/2000 regarding the authority of the province as an autonomous region. This ministerial decree was later revised to Kepmendiknas No. $129 / \mathrm{U} / 2004$ which was adapted to the national education management system in which nonformal education, youth, sports, and early childhood education were emphasized. Talking about operational costs, it cannot be separated from what is known as School Operational Assistance (BOS). Instructions for the use of BOS in education in Indonesia are listed in Permendikbud Number 8 of 2017 concerning Technical Instructions for School Operational Assistance. However, this regulation was subsequently revised again into Permendikbud Number 26 of 2017 concerning Amendments to Permendikbud Number 8 of 2017 Regarding Technical Instructions for School Operational Assistance. Judging from the objectives based on this regulation, it is found that BOS is used only to help with school operational costs outside of the personal costs of students, although there are still some personal costs that can be paid through this BOS. With the existence of BOS, the government aims to reduce the dropout rate. 
Education financing policies in Indonesia generally cover three types of financing, namely operational costs, investment costs, and personal costs. These three costs are considered to be the costs needed to provide education in Indonesia. Although these three costs are not directly borne by the government, the government still needs to pay attention to these three costs. Moreover, in the fiscal decentralization financing policy, it was found that there were still gaps that could be used to finance human resource development in Indonesia[6]. Education as a form of human resource development in Indonesia is certainly worthy of this additional financing. There are various kinds of problems in financing education in Indonesia. Various policies and regulations have been issued by the government to overcome these problems. From BPS data, it is found that most of the poor students at the district and city level are vulnerable to be able to continue their education to a higher level.[7]. Furthermore, the rate of dropping out of school due to poverty, according to BPS, actually reached $73 \%$ in 2016[8].

Based on the above financing problems, strategies can be formulated to overcome them as follows:

a. The first strategy is to allocate financial resources according to the needs of local schools. In this section financial resources are used to meet all the needs of the school. So that schools can receive financial assistance directly without going through the local government. So, the existing funds are directly given to the school for operational and personal costs of the school.

b. The second strategy is the differentiation between assistance to local government and schools. The central government must be able to differentiate or differentiate between the assistance provided to local governments and also to schools. The central government can provide financial assistance in both technical and operational forms to local governments and schools. Of course, this assistance is tailored to the needs of the local government and existing schools.

c. The third strategy is to provide resources to those most in need. In this case, the government must look at which areas are most in need in that area, the government allocates the most resources and financial assistance. So that the areas that are most in need can be parallel to other areas.

d. The fourth strategy is to utilize government financial resources for poor students. This strategy has been met with BOS and KIP for direct and indirect education funding assistance.

e. Track and monitor all expenditures, in this strategy, the government is expected to track and monitor all education expenditures so that there are no leakages. By minimizing leakage, namely corruption, there will be no funds that are wasted or not conveyed.

\subsection{Quality Control in Decentralization of Education}

In the era of decentralization of education, quality assurance is needed to ensure the implementation of the same quality in all education units. There are two approaches used to control the quality of education in Indonesia according to the World Bank (2004). The first approach is quality assurance or control, this approach ensures that schools meet existing quality standards. This approach leads to a school accreditation system. In this system, all school management has a quality standard set by the government. Therefore, each school's achievement will be measured in implementing the existing standards. this approach is the quality assurance for schools. There are at least three objectives of this approach, namely:

a. Equality: creating a similarity between the abilities of teachers and school leavers through an official measurement and assurance. 
b. Justice: ensuring all children, whether they are able or not, get a proper education for all.

c. Laying the foundation: making the same basis for education for the community so that the quality of education is guaranteed and can be improved.

Based on the objectives above, the alternative strategies that can be used for quality control are:

a. Support national programs, local government projects, and school development. When the two approaches on quality assurance and school quality have been implemented, the role of the central government is automatically redefined. This role is to prevent schools from managing their plans, dismantling corrupt systems so that resources are not used in vain, creating standardized and regular programs, adapting policies that can improve the quality of education, creating training centers that can accommodate local government needs.

b. Adapt the Balanced Scorecard system approach to planning and managing assistance to local governments and schools. The Balanced Scorecard is a system that can help an education manager to organize and monitor the process of implementing education. In this system, four areas are regulated which allow this to happen, namely: finance (including human resources, infrastructure, and other resources), conditions for minimal learning, stakeholder satisfaction, and policies and regulations. These four things are the basic concepts of accreditation.

\section{Conclusion and Suggestion}

The education decentralization policy is in line with the mandate of the 1945 Indonesian Constitution. However, with the diversity of conditions in Indonesia, this policy is still not fully implemented. Although the development of its implementation shows an increase from year to year, there are still areas that are lagging behind both in school participation rates and the implementation of education. In this study, it was found that there are at least three strategic issues that play a role in the implementation of decentralization of education in Indonesia. The first issue is about financing, the second issue is regarding quality control and the third issue is regarding teacher professionalism in the world of education. The middle course of these three issues was taken and it was found that they both needed cooperation between the central and local governments as well as schools. Local governments need to control the implementation of education in schools. Then from that control and support also lies with the central government. Thus, although the decentralization of education, the central government does not immediately give up its hands, it still performs the function of control and support.

\section{References}

[1] B. P. Statistik, Potret Pendidikan Indonesia Statistik Pendidikan 2018. Jakarta: Badan Pusat Statistik, Jakarta-Indonesia, 2018.

[2] The World Bank, EDUCATION IN INDONESIA : MANAGING THE TRANSITION TO DECEHNTRALIZATION, vol. 1, no. 29506. 2004.

[3] S. Octavianus, "The Cultivation of Indonesia's Education Financing Policy in Disruption Era," Int. J. Adv. Soc. Econ., vol. 1, no. 1, p. 16, 2019, doi: 10.33122/ijase.v1i1.36. 
[4] Fironika, "Pembiayaan Pendidikan Di Indonesia," J. Pendidik. Dasar, pp. 43-64, 2015.

[5] M. . Imron, "Manajemen Pembiayaan Sekolah," Al-Ibrah, pp. 69-93, 2016.

[6] F. R. Sandjaja, F. Nafisa, and I. N. Manurung, "The Impact of Fiscal Decentralization on Welfare in Selected Provinces in Indonesia," J. Bina Praja, vol. 12, no. 1, pp. 2131, 2020, doi: 10.21787/jbp.12.2020.21-31.

[7] D. Sinaga, "Tingginya Angka Putus Sekolah di Indonesia," CNN Indonesia, 2017. .

[8] Heri, “Angka Putus Sekolah," News Radio Idola, 2016. . 